\title{
Diversity of longhorned beetles (Coleoptera: Cerambycidae) in the Caribbean region of Colombia: temporal variation between two fragments of tropical dry forest
}

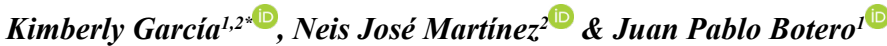 \\ ${ }^{1}$ Universidade de São Paulo, Museu de Zoologia, Laboratório de Coleoptera, São Paulo, SP, Brasil. \\ ${ }^{2}$ Universidad del Atlántico, Facultad de Ciencias Básicas, Programa de Biología, Semillero de Investigación \\ Artrópodos NEOPTERA del Caribe Colombiano, Atlántico, Colombia. \\ *Corresponding author: kimberly.pg@gmail.com
}

GARCÍA, K., MARTÍNEZ, N.J., BOTERO, J.P. Diversity of longhorned beetles (Coleoptera: Cerambycidae) in the Caribbean region of Colombia: temporal variation between two fragments of tropical dry forest. Biota Neotropica 21(3): e20201136. https://doi.org/10.1590/1676-0611-BN-2020-1136.

\begin{abstract}
The tropical dry forest is under constant threat from many anthropic activities which are conducted indiscriminately, modifying the forest, and therefore, affecting species that are closely related to its phenology, such as longhorned beetles (Cerambycidae). The spatio-temporal variation of the cerambycid diversity in two fragments of tropical dry forest (Reserva Campesina la Montaña and La Flecha) in the Caribbean region of Colombia was analyzed. At each locality, four squared plots were delimited, and the beetles were collected with fruit traps, beating sheets and manual capture, and with light traps in the center. Five hundred eighty-seven specimens representing 128 species were collected, of which members of the tribe Ectenessini (Cerambycinae) were the most abundant. At the subfamily level, Cerambycinae was the most abundant (465 specimens) and diverse ( 73 species), followed by Lamiinae and Prioninae. The highest values of richness (110 species), abundance (428), biomass ( $21.18 \mathrm{~g})$, and as well as the highest values of true diversity $(1 \mathrm{D}=73.44,2 \mathrm{D}=34.30)$ were found during the first precipitations. Regarding beta diversity, temporal variation was determined and mainly explained by a high percentage of turnover $(>70 \%)$. Lastly, the high diversity of Cerambycidae was associated with high values of relative humidity and canopy cover during the rainy season. This showed that the structure of the cerambycid community in the tropical dry forest of the Caribbean region of Colombia depends on these variables, which are closely related to precipitation. Keywords: Abundance; biomass; cerambycid; Neotropical; richness, structure.
\end{abstract}

\section{Diversidade de besouros serra-pau (Coleoptera: Cerambycidae) na região caribenha da Colômbia: variação temporal entre dois fragmentos de floresta seca tropical}

Resumo: A floresta seca tropical está sob constante ameaça devido às muitas atividades antrópicas que são realizadas indiscriminadamente, modificando a floresta e, portanto, afetando espécies que se encontram muito relacionadas com a sua fenologia, tais como os besouros serra-pau (Cerambycidae). Foi analisada a variação espaço-temporal da diversidade de cerambícidos em dois fragmentos de floresta seca tropical ("Reserva campesina La Montaña e La Flecha") na região caribenha da Colômbia. Em cada localidade, quatro quadrantes foram delimitados e os besouros foram coletados usando armadilhas com isca de fruta, guarda-chuva entomológico, captura manual e armadilhas de luz. Quinhentos e oitenta e sete espécimes, de 128 espécies foram coletados, sendo os membros da tribo Ectenessini (Cerambycinae) os mais abundantes. Ao nível de subfamília, Cerambycinae foi a mais abundante (465 espécimes) e diversa (73 espécies), seguida de Lamiinae e Prioninae. Os valores mais altos de riqueza (110 espécies), abundância (428) e biomassa (21.18 g) foram encontrados durante as primeiras chuvas, assim como os valores mais altos de diversidade verdadeira $(1 \mathrm{D}=73.44,2 \mathrm{D}=34.30)$. Em relação à diversidade beta, a variação temporal foi determinada e principalmente explicada por uma alta porcentagem de substituição ( $>70 \%)$. Por último, uma alta diversidade de Cerambycidae foi associada com altos valores de humidade relativa e cobertura vegetal durante a temporada de chuva, mostrando que a estrutura da comunidade de Cerambycidae na floresta seca tropical da Colômbia depende dessas variáveis, as quais são muito relacionadas com a precipitação.

Palavras-chave: Abundância; biomassa; cerambicídeos; Neotropical; riqueza; estrutura. 


\section{Introduction}

Originally in Colombia, the tropical dry forest (TDF) was very extensive, but today it has been reduced to less than $10 \%$ of its original area, of which only about $5 \%$ is under protection (Rodríguez et al. 2012, Pizano \& García 2014). The departments with the highest TDF coverage in Colombia are in the Caribbean region (Acevedo 2016), where Atlántico and Bolívar stand out with the highest percentages (5,7\% and 4,1\%, respectively) (Otero et al. 2006, Pizano \& García 2014). Tropical dry forest in these departments is represented by small fragments isolated from each other, surrounded by agricultural ecosystems, pastures, living fences, paths, and plantations (Otero et al. 2006, Rangel \& Martínez 2017). However, these fragments provide habitat, resources, and specific environmental conditions for native fauna, constituting an important refuge and biodiversity reserve (Kattan \& Álvarez-López 1996, Otero et al. 2006, Rangel \& Martínez, 2017).

In order to conserve this ecosystem it is critical to know the temporal dynamics of the diversity of groups of great importance such as the longhorned beetles (Coleoptera: Cerambycidae), due to their high sensitivity to the changes in the floristic composition caused by the alteration of environmental variables, such as temperature, thermal radiation, and relative humidity (Bouget 2005, Baselga 2008), from one season to another. This sensitivity results from a decrease in the availability of host plants for cerambycid species, as well as a reduction in resources and reproduction sites (Hjältén et al. 2012) negatively altering the distribution, taxonomic composition, and diversity of the family (Maeto et al. 2002). Lastly, factors such as climate change, which is constantly affecting the TDF in the Caribbean region of Colombia (Miles et al. 2006), produces high mortality of cerambycid larvae and decreases species diversity (Haack et al. 2017). Also, it is important to know the dynamics of these beetles as they perform ecological functions such as secondary pollination (Maeto et al. 2002) and decomposition of senescent and dead trees, contributing to the cycle of minerals and nutrients into the soil (Martínez 2000, Noguera 2014).
The structure and spatial variation of the cerambycid community is not expected to change because tropical dry forest in most of the Caribbean region of Colombia are very similar in their general characteristics (Otero et al. 2006), and offer a vegetal diversity favorable to the development of these beetles, which are closely related to the type of the forest and the size, development, and composition of the vegetation in a delimited area (Meng et al. 2013, Sataral et al. 2015, Sugiarto et al. 2016).

Accordingly, our hypothesis for this study was that the community structure should present a marked seasonality due to the close relationship between Cerambycidae and the phenology of TDF in the Caribbean region of Colombia. To test our hypothesis we analyzed the temporal variation of the community of longhorned beetles in two fragments of TDF (Reserva Campesina La Montaña and Reserva La Flecha) in the Caribbean region of Colombia.

\section{Materials and Methods}

\section{Study area}

Two fragments of TDF in the Caribbean of Colombia were chosen: Reserva Campesina la Montaña (RCM), located in the department of Atlántico, and Reserva La Flecha (RLF), in the department of Bolívar (Figure 1).

The RCM is located around the coordinates $10^{\circ} 46^{\prime} 2.6^{\prime \prime} \mathrm{N}, 75^{\circ} 0.2^{\prime} 34^{\prime \prime}$ $\mathrm{W}$, at an altitude between 150 and $260 \mathrm{~m}$ (Vargas et al. 2015). The average temperature is $27^{\circ} \mathrm{C}$ and the relative humidity around $62 \%$ (García-Atencia \& Martínez-Hernández 2015). The rainy season runs from April to November and the dry season from December to March (Rangel-Ch \& Carvajal-Cogollo 2012). This fragment comprises 47 ha (Figure 1a) that are surrounded by farms, felling activities and controlled burning, which have disturbed the original forest cover in recent years (García-Atencia \& Martínez-Hernández 2015). According to Holdridge's (1978) classification, the vegetation is hygrotrophophytic, losing most of the canopy layer during the dry season.

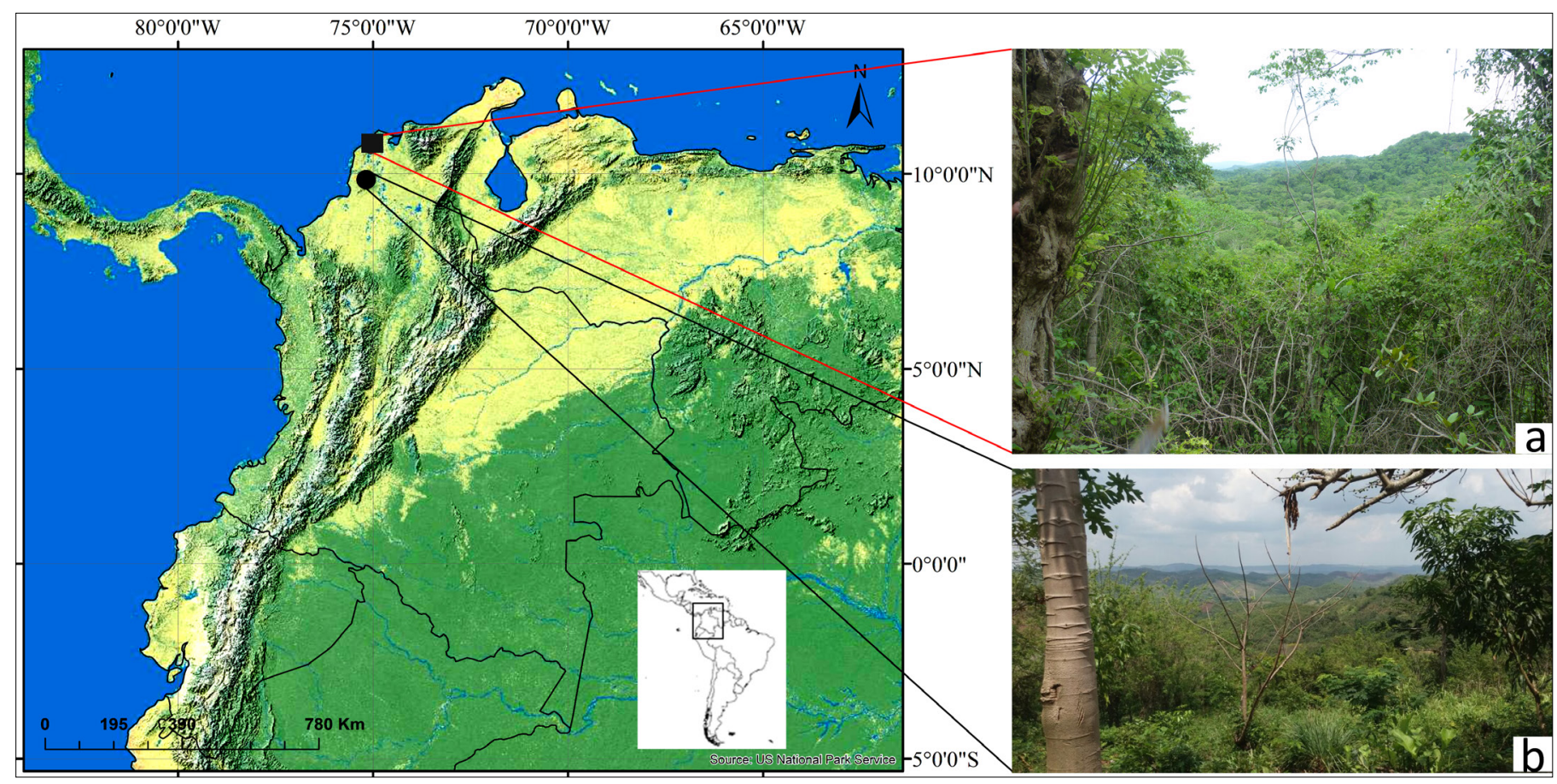

Figure 1. Study Area. a. Reserva Campesina la Montaña (RCM), Atlántico (square); b. Reserva La Flecha (RLF), Bolívar (circle). Adapted from García-L, Nascimento \& Martínez-Hernández (2019). 
The RLF is located at the median part of the Caribe plain, around the coordinates $09^{\circ} 51^{\prime} 12.4^{\prime} \mathrm{N}, 75^{\circ} 10^{\prime} 41.4$ ' $\mathrm{W}$, at an altitude between 324 and $500 \mathrm{~m}$. The average temperature is $25^{\circ} \mathrm{C}$ and the relative humidity $75 \%$. The rainfall regime is bimodal, with a period of intense drought between December and March, and the rainy season from April to June and from August to November (approx. $25 \mathrm{~mm} / \mathrm{month}$ ) (Rangel-Ch \& Carvajal-Cogollo 2012). This fragment comprises 149 ha (Figure 1b) and is also surrounded by pastures, annual and perennial crops, and plant succession areas. These activities, such as burning, cutting trees and livestock grazing have caused a decrease of this forest, making this region a priority to become a protected area (Pizano \& García 2014). According to Holdridge's (1978) classification, the vegetation is subhigrophic, whereby the evergreen vegetation is present (Villareal et al. 2019).

\section{Sampling design}

At each fragment, we performed four samplings: two during the dry season $(0 \mathrm{~mm} / \mathrm{month})$, one in February and the second one in March, and two in the rainy season (150-280 mm/month), one in April/May and the second one in June. Each sampling lasted eight days, four days in one locality, and the next four days in the other. At each locality, four squared plots of 50x50 m were delimited, $350 \mathrm{~m}$ from each other (Figure 2). A point was placed on each vertex of the square plot (four points/plot), where the Cerambycidae were collected with fruit-baited traps (F.T), beating sheet (B.S) and manual capture (M.C). In the center, a fifth point was marked, where a light trap (L.T) was installed.

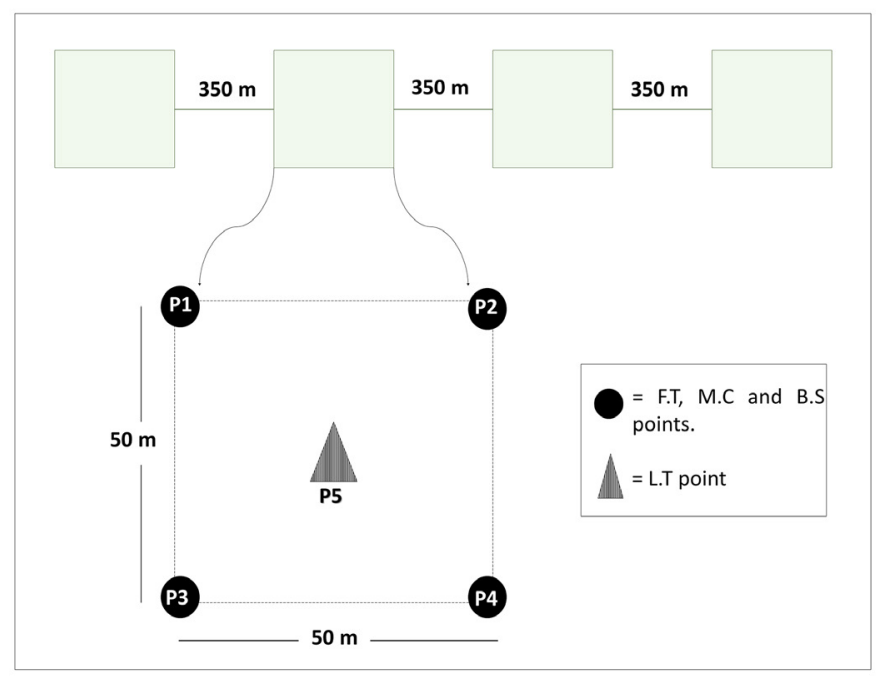

Figure 2. Sampling design and position of each technique point.

The F.T consisted of a cylindrical receptacle with two plastic funnels (diameter: $6 \mathrm{~cm}$ ) positioned on the lateral margin of the trap, projected inward (Supplementary Material 1A). Inside the receptacle, an attractant (fermenting fruit) was included, which contained ripe banana (from the plant Musa paradisiaca L.), red wine, vanilla essence, and raw cane sugar. The F.T were placed at an elevation between 2-4 m, remained in the field for 48 hours, and were checked every 24 hours. The B.S was conducted with a wooden mallet and a fabric sheet (diameter: 80 $\mathrm{cm}$, depth: $13 \mathrm{~cm}$ ) (Supplementary Material 1B). This technique was performed with an intensity of 80 beats per point, at a distance of $10 \mathrm{~m}$ from the central point. The B.S sampling was conducted during the day, focusing on bushes, flowers, and small trees. The M.C sampling was conducted during the day and night, with an intensity of 20 minutes per point (Supplementary Material 1C), focusing on foliage, bark of trees, wood, flowers, and fruits. The L.T consisted of a rectangular acrylic sheet $(30 \times 50 \mathrm{~cm})$, with a lamp on each side (two plots with white lights, and two with UV lights). A collection receptacle was placed under the acrylic sheet with a solution of alcohol (70\%), salt and detergent (Supplementary Material 1D). The L.T were turned on at $6 \mathrm{pm}$, only on new moon nights.

The environmental parameters were measured with an Extech (RHT10) datalogger placed at the center of each square plot (to record ambient temperature and relative humidity), and a Hellman rain meter at each sampling site to register daily precipitation $\left(\mathrm{mm}^{3}\right)$ at each season. The canopy cover was measured with a spherical crown densitometer, according to Valdez et al. (2006).

The specimens are deposited in the entomological collection of the Universidad del Atlántico, Colombia (UARC), of the Pontificia Universidad Javeriana (MPUJ) and the Museu de Zoología da Universidade de São Paulo, Brazil (MZSP).

\section{Data analysis}

Cerambycid richness was calculated as the number of species captured by season and fragment. Abundance was determined as the number of individuals of each species. For biomass analysis, 10 random individuals of each species were selected. These were dried for 20 days under an incandescent lamp (Cancino et al. 2014). Later, we calculated the average weight of one individual with a portable electronic scale (Model Ohaus Adventurer of $220 \mathrm{~g} \pm 0.00001$ ) and multiplied by the total number of specimens per species to obtain biomass data.

These variables were compared, between localities and seasons, with the non-parametric analysis Kruskal-Wallis and a Mann-Whitney pairwise comparison to calculate the statistical significance a posteriori. This analysis was conducted with the software PAST version $2.17 \mathrm{~b}$ (Hammer et al. 2001). To represent richness, equitability, and relative abundance by season and fragment, a range-abundance curve was developed (Whittaker 1965). The biomass was also included in this curve (Trapero \& Reyes 2017). These analyses were performed with the software PRIMER 6.0 (Clarke \& Gorley 2006) and MS Excel.

Alfa diversity was estimated as "true diversity" using the effective numbers of species, according to the diversity orders sensu Jost (2006) $\left({ }^{0} \mathrm{D},{ }^{1} \mathrm{D}\right.$ and $\left.{ }^{2} \mathrm{D}\right)$. This analysis was performed with the software iNEXT version 1.3.0 (Chao et al. 2014). Following Baselga (2010), the proportion of the components of beta diversity $\left(\mathrm{B}_{\text {sor }}\right)$ : nestedness $\left(\mathrm{B}_{\text {nes }}\right)$ and turnover $\left(\mathrm{B}_{\text {sim }}\right)$, between season-fragments, were calculated with the software Betapart package (Baselga \& Orme 2012).

We also conducted a non-metric multidimensional scaling analysis $(n M D S)$ to explore spatial and temporal patterns of the community (Bray \& Curtis 1957, Meng et al. 2013). Previously, data were transformed into $\log _{\mathrm{e}}(\mathrm{x}+1)$ and a Bray-Curtis similarity matrix was produced. To establish if the patterns obtained in the $n M D S$ were significant, an ANOSIM test $(p<0.05)$ was performed (Meng et al. 2013). These statistics were generated with the software PRIMER 6.0 (Clarke \& Gorley 2006). Lastly, a Canonical Correspondence Analysis (CCA) (Ter-Braak 1986) was performed to determine the relation between the relative abundance of each species and the environmental variables. The 
singleton specimens were eliminated to increase precision. This analysis was performed with the software R and the packages MASS (Venables \& Ripley 2002) and VEGAN (Oksanen et al. 2017).

\section{Results}

\section{Composition of Cerambycidae species}

A total of 587 specimens from three subfamilies, 30 tribes and 128 morpho-species were collected, of which 115 were identified to species, eight to generic level, and 5 to tribal level (Supplementary Material 2). At the RCM we collected 81 species from 22 tribes, and at the RLF we collected 78 species from 23 tribes. The subfamily Cerambycinae was the most abundant and rich, representing $79.22 \%$ of the total number of specimens and $57.03 \%$ of the species, followed by Lamiinae with $19.6 \%$ of the abundance and $39.85 \%$ of the richness, and lastly the subfamily Prioninae, with just $1.19 \%$ of the abundance and $3.12 \%$ of the total amount of species.

In Cerambycinae, the highest number of species and specimens were registered for Elaphidiini, followed by Hexoplonini, Eburiini and Neoibidionini. In Lamiinae, the most represented tribes were Acanthoderini and Acanthocinini. In the subfamily Prioninae, all four species belong to Macrotomini (Supplementary Material 2).

\section{Richness, abundance and biomass of Cerambycidae}

During the rainy season, the highest value of richness $(S=110)$ was registered, very distinct from the dry season $(S=30)$. The KruskalWallis test determined that there is statistical significance in the richness between seasons, and the Mann-Whitney test allowed us to establish that these differences are mainly between the rainy season in the RCM and the dry season in both fragments (Supplementary Material 2). Regarding the abundance, in the RCM we collected 328 specimens (114 during the dry season and 214 during the rainy season), while in the RLF we registered 259 specimens (45 in dry season and 214 during the rainy season). Lastly, the highest biomass value was found in the RLF during the rainy season, and the lowest value during the dry season in both fragments. According to the Kruskal-Wallis test and the Mann-Whitney test, there is no statistical difference $(\mathrm{p}>0.05)$ in the abundance nor in biomass by fragment and season (Supplementary Material 2).

\section{Dominance, evenness, and relative abundance of Cerambycidae species}

The highest dominance was registered during the dry season in the RCM, where Ectenessini sp. was the most dominant $(\mathrm{N}=89)$, and the common species were Lissonotus corallinus Dupont, $1836(\mathrm{~N}=6)$, Ysachron pilosus $(\mathrm{N}=4)$, and Diploschemopsis howdeni (Martins \& Monné, 1980) $(\mathrm{N}=3)$ (Figure 3a). Additionally, we found nine more species represented by one or two specimens. Regarding the rainy season of this particular fragment, Sphaerion costae García \& Nascimento, 2020 was the dominant species $(\mathrm{N}=41)$, Psiloibidion boteroi García, 2019, and Neocompsa glaphyra Martins, 1970 were registered as common species with 21 and 18 specimens respectively (Figure 3a). In addition, in this sampling we found 69 species with less than 10 specimens.

The highest evenness was registered in the RLF during the rainy season (Figure 3a), where the abundance was distributed in five species: Diasporidion duplicatum (Gounelle, 1909) (N=17),
Tropidion litigiosum Martins, $1968(\mathrm{~N}=15)$, Sphaerion costae $(\mathrm{N}=$ 15), Limernaea ochracea (Fisher, 1927) ( $\mathrm{N}=14)$, and Piola colombica Martins \& Galileo, $1999(\mathrm{~N}=12)$. In addition to these species, 56 rare species were added, in which $64.3 \%$ were registered with only one or two specimens. Lastly, during the dry season in this fragment, we found the lowest richness and abundance of species overall (Figure 3a). Moreover, the most abundant species had less than 10 individuals Ysachron pilosus García, Botero \& Santos-Silva, 2021, and the common species (Ectenessa wappesi Galileo \& Santos-Silva, 2016, Beraba marica Galileo \& Martins, 1999, Ceragenia insulana Fisher, 1943, and Aegomorphus circumflexus (Jacquelin Duval, 1857)) less than four. Eighteen rare species were registered in this sampling.

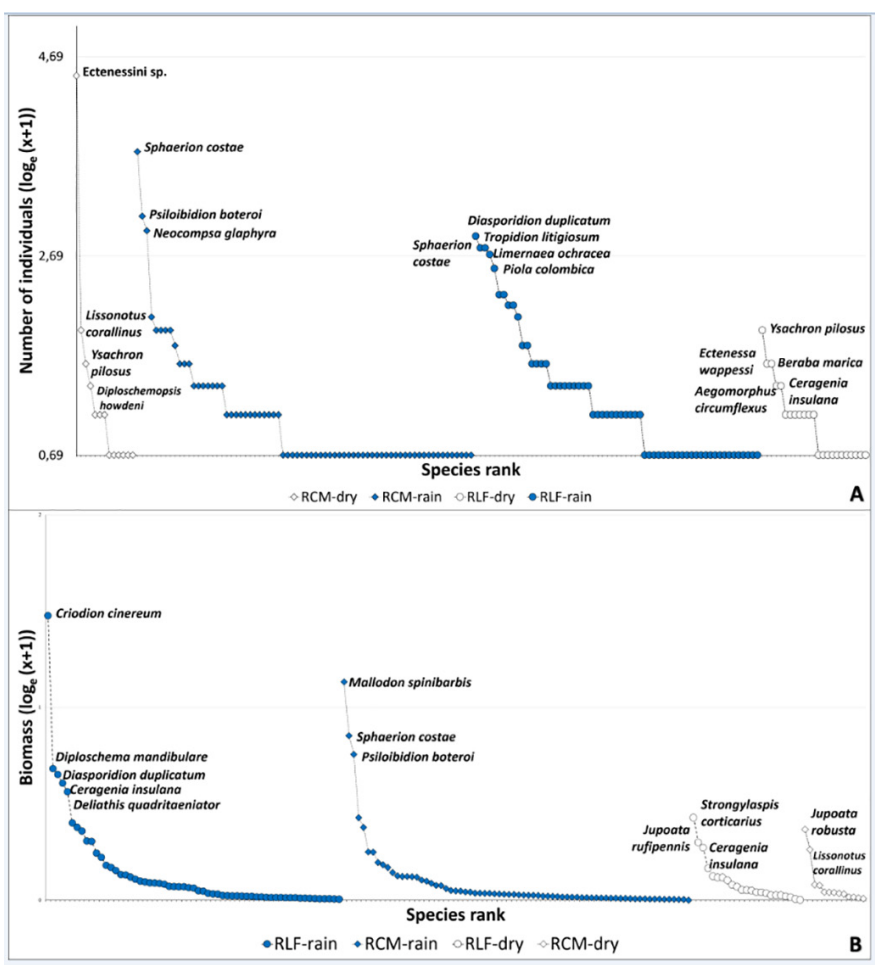

Figure 3. Whittaker plot of abundance (a) and biomass (b) of Cerambycidae species per season on each fragment.

Regarding the biomass, the biggest contribution was during the rainy season (Figure $3 b$ ). The highest biomass was registered in the RLF, and Criodion cinereum (Olivier, 1795) stood out as the dominant species $(\mathrm{N}=3$, $\mathrm{B}=3.4 \mathrm{~g}$ ). During the dry season, Strongylaspis corticarius (Erichson, 1848) $(\mathrm{N}=2, \mathrm{~B}=0.53 \mathrm{~g})$, Jupoata rufipennis (Gory, 1831) $(\mathrm{N}=1, \mathrm{~B}=0.35 \mathrm{~g})$, and Ceragenia insulana $(\mathrm{N}=3, \mathrm{~B}=0.31 \mathrm{~g})$ were dominant. As for the $\mathrm{RCM}$, Mallodon spinibarbis (Linnaeus, 1758) was the dominant species during the rainy season $(\mathrm{N}=2, \mathrm{~B}=2.1 \mathrm{~g})$. Other species such as Sphaerion costae $(\mathrm{N}=41,1.35 \mathrm{~g})$ and Psiloibidion boteroi $(\mathrm{N}=21, \mathrm{~B}=1.13 \mathrm{~g})$ stand out for having a medium size and high abundance making a relevant contribution to biomass. The dry season in general presented low values of biomass; Jupoata robusta Martins \& Monné, $2002(\mathrm{~N}=1, \mathrm{~B}=0.44 \mathrm{~g})$ and Lissonotus corallinus $(\mathrm{N}=6, \mathrm{~B}=0.30 \mathrm{~g})$ were dominant species.

\section{4. $\alpha$ diversity}

A total of 128 species were collected, of which a significant amount was registered during the rainy season (Supplementary Material 2). 
The lowest value of the effective number of species (0D, 1D, 2D) was registered in the RCM during the dry season. Seventy-two species were registered in the RCM, and 61 in the RLF. Regarding the diversity order ${ }^{1} \mathrm{D}, 47$ species were registered, mainly during the rainy season, 39 in the RLF and 35 in the RCM. Lastly, alfa diversity of abundant species $\left({ }^{2} \mathrm{D}\right)$ was higher in the RLF during the rainy season; for the dry season in the RLF and rainy season in the RCM, the same values were registered $(S=16)$.

\section{4. $\beta$ diversity}

A total of 31 species were registered as shared between fragments, 50 exclusive for the RLF and 47 for the RCM. Regarding the seasons, a low number of shared species were registered $(S=12)$, and the rainy season had the highest value of exclusive species $(S=98)$, very different from the dry season $(S=18)$. The beta diversity values were high and explained mainly by turnover. According to the estimation (Jaccard dissimilarity), turnover exceeds $70 \%$ in all the cases, hitting $87 \%$ when comparing the rainy season in the RCM with the dry season in the RLF (Figure 4). Percentages of nestedness are under $14 \%$ in all the cases, and the highest value (13.2\%) was obtained when comparing the dry with the rainy season in the RCM (Figure 4).

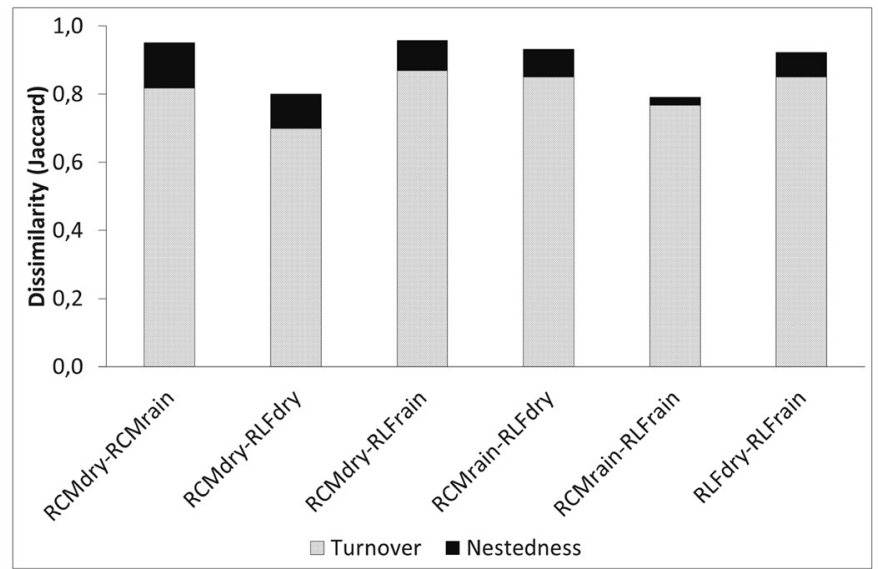

Figure 4. Variation of beta diversity in Cerambycidae community, with percentage of turnover and nestedness in the study area, according to Jaccard dissimilarity index.

\section{Spatio-temporal variation of the Cerambycidae community}

The non-metric multidimensional scaling analysis ( $n M D S$ ) showed that the composition and structure of cerambycid species between fragments form two separate groups, and it can be said that the groups are mainly for the seasons (dry and rainy) rather than the fragments (Figure 5). The results observed on the $n M D S$ agree with the analysis of similarities (ANOSIM), which determined statistical significances in the structure of the community $(\mathrm{R}=0.345, p=0.001)$. In this case, the differences were registered in different seasons between the same or different fragments, and when both fragments were compared at the same season there were no differences (RCM-Dry vs RLF-Dry 0.065 and RCM-Rain vs RLF-Rain 0.054) (Table 1).

\section{Relation of environmental variables and canopy cover with variation of the Cerambycidae community}

Regarding the environmental variables, we measured ambient temperature (AT), relative humidity (RH), canopy cover (CC) and precipitation (prec), as seen in Supplementary Material 3.

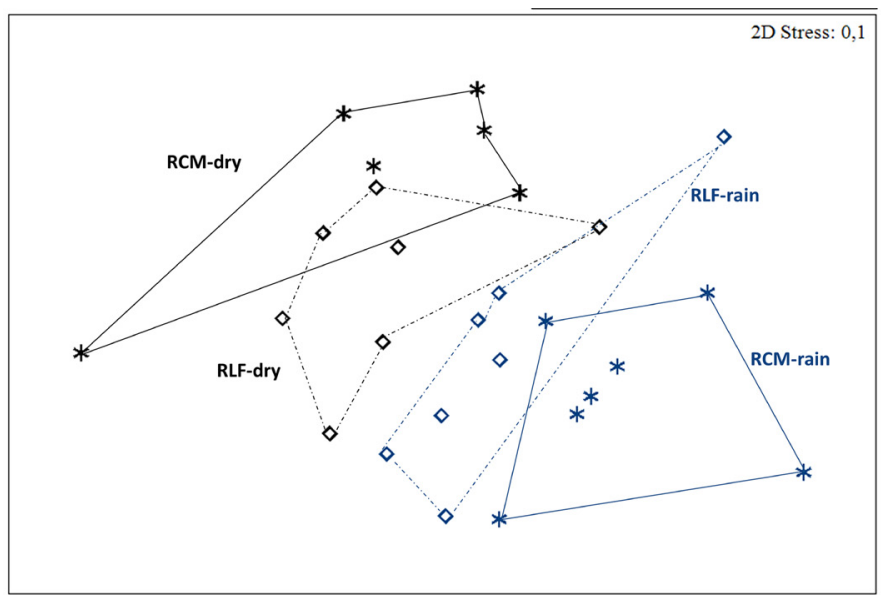

Figure 5. Non-metric multidimensional scaling analysis ( $n M D S)$ based on a Bray-Curtis dissimilarity matrix, which describes the spatio-temporal variation of the Cerambycidae community in the study area.

Table 1. Comparisons of the structure of the Cerambycidae community by seasons and fragments using the analysis of similarities (ANOSIM).

\begin{tabular}{lcc}
\hline Groups & R & Significance level \\
\hline RCM-Dry vs RCM- Rain & 0.451 & 0.002 \\
RCM-Dry vs RLF-Dry & 0.177 & $0.065^{*}$ \\
RCM-Dry vs RLF-Rain & 0.53 & 0.001 \\
RCM-Rain vs RLF-Dry & 0.471 & 0.003 \\
RCM-Rain vs RLF-Rain & 0.138 & $0.054^{*}$ \\
RLF-Dry vs RLF-Rain & 0.327 & 0.01 \\
\hline
\end{tabular}

* Do not have statistical significance

The first two axes of the CCA explained $71 \%$ of the variation of the data and was shown to be statistically significant $(p<0.05)$ (Table 2$)$, registering the highest value $(0.91)$ on the first axis. The variables that contributed the most to this variation were canopy cover (CC), precipitation (Prec) and relative humidity $(\mathrm{RH})$ on the first axis, and ambient temperature (AT) on the second. Also, we observed there is a higher concentration of species when the $\mathrm{CC}$ and $\mathrm{RH}$ increases, which occurred when the highest precipitation was registered, however then the AT increases, and we observed a lower quantity of species (Figure 6).

The abundance of species such as Diploschemopsis howdeni, Ectenessini sp., Compsibidion paradoxum Martins, 1971, Ysachron pilosus and Protumida insularis Monné \& Wappes, 2014, exclusive for dry season, presented a directly proportional relation to AT and inversely proportional to RH and CC. Furthermore, other species were associated with high values of $\mathrm{RH}$ and $\mathrm{CC}$, and inversely proportional to AT, such as Stizocera geniculata (Pascoe, 1866), Gnomidolon bellus Martins \& Galileo, 2002, Lepturges (Lepturges) elegantulus Bates, 1863, Coleoxestia rubromaculata (Gounelle, 1909), Mimasyngenes icuapara Galileo \& Martins, 1996, Beraba piriana Martins, 1997, and B. anae García, Botero \& Martínez, 2019.

\section{Discussion}

On account of the constant threat from many anthropic activities TDF fragments face in the Caribbean of Colombia and the lack of information on the diversity of Cerambycidae, this research represents the first ecological study of the family in Colombia, serving as a pioneer 
García, K. et al.

Table 2. Percentage of explained variation for each axis in the canonical correspondence analysis (CCA). AT: Ambient temperature; RH: Relative humidity; Prec: Precipitation; CC: canopy cover. Variables that contribute the most to the diversity variation in bold.

\begin{tabular}{lcccc}
\hline Variables/ Axes & CCA1 & CCA2 & CCA3 & CCA4 \\
\hline Eigenvalue & 0,9122 & 0,514 & 0,3303 & 0,2518 \\
& 45,42 & 25,59 & 16,45 & 12,5 \\
Explained variation (\%) & $(\mathrm{F}=3,1568 ; \mathrm{p}=0,001)$ & $(\mathrm{F}=1,7787 ; \mathrm{p}=0,014)$ & $(\mathrm{F}=1,143 ; \mathrm{p}=0,523)$ & $(\mathrm{F}=0,8714 ; \mathrm{p}=0,657)$ \\
Accumulated variation (\%) & 45,42 & 71,01 & 87,46 & 100 \\
AT & $-0,3464$ & $\mathbf{0 , 7 0 4 4 3}$ & $-0,5676$ & $-0,24828$ \\
RH & $\mathbf{0 , 6 2 1 4}$ & $-0,68843$ & 0,351 & $-0,12939$ \\
CC & $\mathbf{0 , 9 6 0 4}$ & 0,04455 & 0,2589 & $-0,09276$ \\
Prec & $\mathbf{0 , 9 0 9 4}$ & $-0,38883$ & $-0,1407$ & 0,0442 \\
\hline
\end{tabular}

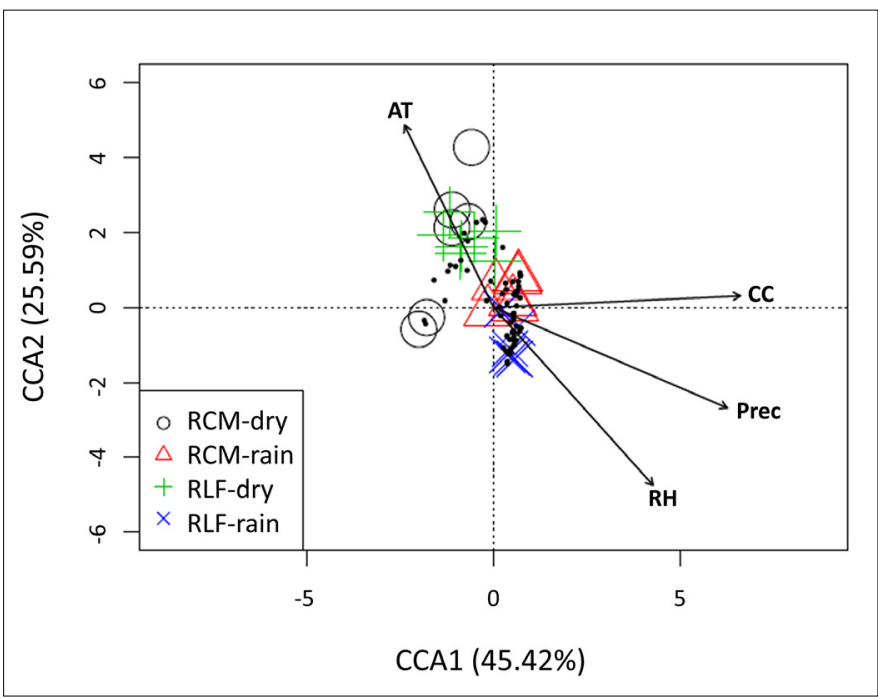

Figure 6. Graphic representation of the canonical correspondence analysis (CCA) based on the interaction of environmental variables (AT: Ambient temperature; RH: Relative humidity; Prec: Precipitation) and canopy cover (CC) with Cerambycidae diversity.

investigation on the region, making contributions to the taxonomy, ecology, and biology of this group. First of all, with this research we were able to identify the cerambycid fauna associated with TDF in the Caribbean region of Colombia, adding 18 new species and 32 new distribution records for Colombia, which are currently published or in press (e.g. García et al. 2019, García 2019, García \& Nascimento 2020). Additionally, 49 species were registered for the first time for Bolívar, and 56 for Atlántico departments. Also, this research demonstrated that the structure of the cerambycid community of TDF, in the Caribbean region of Colombia, presents ecological patterns associated with the vegetation structure and environmental variables determined by seasonal ecosystem conditions.

The highest diversity and abundance of Cerambycinae coincides with the research of Noguera et al. (2002, 2007, 2009, 2012, 2017), who reported this subfamily as dominant in Mexican TDF. In addition, Gutiérrez et al. (2014) mentioned that Cerambycinae is the most common subfamily in dry forest, even though Lamiinae is the most abundant in most of the world and in rain forests. It is not clear what factors act on the differences registered in the pattern of richness of Cerambycinae and Lamiinae between rain and dry forest. Gutiérrez et al. (2014) suggested that these differences could be due to a sampling effect, because most of the Cerambycinae species exhibit diurnal activity and frequent flowers, making their capture easy during the flowering season, especially in dry forests where the trees have an average height of $10 \mathrm{~m}$. However, the rain forest has taller trees, making capture more difficult. Lastly, Prioninae was the least common subfamily in this research, coinciding with the findings of Martínez (2000) and Botero (2018), who mentioned it as the least diverse of the subfamilies found in our study.

Tribes with a great diversity (e.g. Acanthoderini, Acanthocinini, Mallodonini) can be explained by the presence of some of their host plants, in and around the sampling plots, plant species that had been registered in TDF fragments of the Caribbean of Colombia according to Mendoza (1999), Rodríguez et al. (2012), Pizano \& García (2014), and Herazo-Vitola et al. (2017). For example, the presence of Lepturges Bates, 1863, and Urgleptes Dillon, 1956 species (Acanthocinini) is explained by their association with plant species of the genus Acacia (Martius, 1829) (Romero et al. 2007), present in the study area; Steirastoma histrionicum White, 1855 (Acanthoderini) has been associated with plant species such as Ceiba pentranda (L.) Gaertner, and Sterculia apetala Druce (Vitali et al. 2006), plants characteristic from the sampled fragments; and Mallodon dasystomus dasystomus (Say, 1824), and M. spinibarbis, (Mallodonini) have Bursera simaruba (L.) Sarg., and species of the genus Ficus L. as their host plants (Maes et al. 2010), which are also present in the study area.

Regarding the seasons, during the rainy season we observed the highest values of abundance, richness, and biomass of Cerambycidae in the adult stage due to the changes in the dry forest phenology in the area. Due to their sapro-xylophagous behavior, during the dry season the larvae feed on the great quantity of dead wood available (Noguera et al. 2012) and when the rain comes, the resources increase in the forest and so does the activity of the adults of many cerambycid species to feed and mate (Sugiarto et al. 2016, Noguera et al. 2017). These results coincide with Noriega et al. (2007), who did a research on Coleoptera in the Colombian Amazonian, and found that herbivorous beetles (including Cerambycidae), were more abundant during the rainy season. Also, Noguera et al. $(2002,2012,2017)$ found a higher richness and abundance of Cerambycidae during the rainy season on Mexican TDF, where $75 \%$ of the registered longhorn beetles were exclusive to this season.

The unevenness registered is mainly because of a high frequency of singletons and doubletons, a characteristic occurrence of arthropods in Neotropical ecosystems (Cava et al. 2015). The high dominance of Ectenessini sp. during the dry season in the RCM and Ysachron pilosus in the RLF, is due to the small size of these species $(<10 \mathrm{~mm})$, which are characterized for having a high number of individuals, because the 
larvae are able to develop in small logs, frequent in TDF forest, unlike bigger species which could have different microhabitat requirements (Sataral et al. 2015). However, there might be a sampling effect, too, because both species were collected with light trap, which is an active collection method. The even dominance of Diasporidion duplicatum, Tropidion litigiosum, Sphaerion costae, Limenaea ochracea and Piola colombica during the rainy season in the RLF, might indicate a preference of these species for the characteristics of this forest during the rain, however, further studies are necessary to clarify this finding.

The highest values of biomass during the rainy season in the RLF can be explained because during the rainy season we registered the lowest temperatures, which allows larger species to thermo-regulate because the surface/volume ratio decreases and consequently, the energy expenditure (Amat 2007). This is very important because thermoregulation in herbivorous insects is essential for controlling the energy expenditure on digestion and absorption of nutrients (FuentesRodríguez et al. 2017). Lastly, a higher biomass during the rainy season is also due to the biggest individuals belonging to the subfamily Prioninae, in which almost all species are nocturnal and crepuscular, and are easily attracted to artificial lights such as the ones we used in our sampling (Švácha \& Lawrence 2014).

The lowest biomass during the dry season is mainly because of the high frequency of small cerambycid species (less than $0.5 \mathrm{~g}$ each). These values are important because they allowed us to recognize which species contribute the most in the primary production of the ecosystem, participating in the reallocation of nutrients (Noriega et al. 2012), and influencing the TDF services and functionality.

Alfa diversity for all three orders $\left({ }^{0} \mathrm{D},{ }^{1} \mathrm{D},{ }^{2} \mathrm{D}\right)$ is similar, when comparing the sampling places, probably because both forests have similar vegetation structure, containing host plants of many Cerambycidae species, so it is expected that both places will have a similar diversity of Cerambycidae as well, as the species will have enough resources in either of them. This pattern concurs with the research of Noguera et al. (2017), who showed a close relationship between the richness of plants and the richness of Cerambycidae in the Mexican TDF. Additionally, the highest diversity during the rainy season is because precipitation brings about changes in the foliage, a higher availability of habitats and flowering of many vegetal species (Pizano \& García 2014), which are key to developmental activities such as reproduction of these beetles (Švácha \& Lawrence 2014), and a greater availability of resources for the posterior development of the larvae. In this case, some species appear to co-evolve with their host plants (Farrell \& Mitter 1998), synchronizing the adult stage with the season that offers more and better resources (Noguera et al. 2017).

We registered a high beta diversity mainly explained seasonally, which indicates a high environmental heterogeneity (Morrone \& Escalante 2016). High levels of environmental heterogeneity are an answer to a well-marked seasonality of TDF in the Caribbean region of Colombia, influencing the recorded beta diversity by three mechanisms. The first mechanism are the ambient conditions which change from dry season to rainy season on each fragment, this implies that there is a separation of species with different physiological characteristics, which allows them to have niche difference between seasons on each place; the second one depends on the configuration of the environment, because the dry forest seasonality causes a low similarity within the same locality because of the environment heterogeneity; the third one depends on the capacity of dispersion of the species, because many species are not able to disperse for the barriers created by the environmental heterogeneity between both localities (Martínez et al. 2010, Pizano \& García 2014, Villareal et al. 2019). Also, taking into account the geological history of TDF in Colombia, its original extension was reduced due to geological and climatic processes, and recently for anthropic interference (Kattan et al. 2019, Suarez \& Vargas 2019).

The high beta diversity due to turnover can be explained spatially: the deforested areas between the forest fragments, which possibly were a continuum of TDF in the Caribbean of Colombia, represent a geographic barrier for those species closely related to their host plants (Pérez \& Zaragoza 2015). In addition, turnover is also a result of the geographic size of forest fragments and habitat restriction (Harrison et al. 1992, Morrone \& Escalante 2016), because the species are specific in their requirements, so their distribution is also restricted, forming groups with greater differences between each other (Rodríguez et al. 2003, Morrone \& Escalante 2016).

Moreover, the low nestedness registered in this research is due to differentiation on the composition of species by the presence of barriers or patterns of selective differentiation between both localities, so they were not found in a wide range of environmental variation or geographic distribution (Baselga 2010). The above is because the composition of the communities between both localities are not a subgroup of richer communities in terms of species (Calderón-Patrón et al. 2012). Lastly, is important to take into account that the preferences of each species for its habitat or certain environmental conditions are not only for the advantage these factors offers for survival, but it is also probable that is an evolutionary component, to co-exist and decrease competition, throughout the processes of speciation. In this way, it is proposed as hypothesis that those macroecological causes also models the high beta diversity founded in this study (Morrone \& Escalante 2016).

The highest diversity of Cerambycidae associated with high values of canopy cover $(93.21 \% \pm 2.07)$ during the rainy season could be explained by the fact that some beetles have adapted to microclimatic changes of vegetation and the availability of resources which proliferate in the canopy and soil, as explained for Onciderini (Cerambycidae, Lamiinae) (Paro et al. 2014) and even for Scarabaeidae (Martínez et al. 2010). This finding concurs with Sugiarto et al. (2016) and Gatti et al. (2018), who reported a higher diversity and dominance of Cerambycidae when canopy cover is higher. Furthermore, the close relation of high relative humidity $(79.1 \% \pm 1.92)$ and high cerambycid diversity, can be explained by how this variable influences wood decomposition, main food source of Cerambycidae larvae (Toledo et al. 2014, Noguera et al. 2017), coinciding with Noguera et al. (2017) study, who reported that Cerambycidae adults use death matter for larvae development, and this resource is derived from branches on the ground which could fell off for the increase of weight caused by high humidity.

The low quantity of cerambycid species related to high temperature is because this variable has a negative effect on certain functions performed by the beetles, such as wood degradation (Noriega et al. 2007). In addition, it also produces dehydration and loss of the forest canopy, decreasing the quantity of available resources for Cerambycidae (Martínez et al. 2010).

These results demonstrate that there is a temporal variation of the structure of the cerambycid community in the study area, in which the abundance, richness, and biomass are higher during the rainy season, 
mainly explained by the high turnover of species from one season to another. Therefore, we conclude that TDF represents an ecosystem with a high cerambycid diversity, especially during the rainy season. It is critical to monitor these populations to evaluate the impact of anthropic activities on these remaining fragments in the Caribbean region of Colombia. This study also represents a practical approach to the study of diversity patterns of understudied groups in TDF such as the Cerambycidae in Colombia.

\section{Supplementary Material}

The following online material is available for this article:

Supplementary material 1 - Sampling techniques used; fruit-bated trap (a), beating sheet (b), manual capture (c), light trap (d).

Supplementary material 2 - Richness (S), abundance (N) and biomass (in parenthesis) of Cerambycidae species registered in the study area. RCM-d: Reserva Campesina la Montaña, dry season; RCM-r: Reserva Campesina la Montaña, rainy season; RLF-d: Reserva La Flecha, dry season; RLF-r: Reserva La Flecha, rainy season; S.T: Sampling technique; MC: Manual capture; FT: Fruit-bated trap; BS: Beating sheet; WLT: White light trap; UVLT: UV light trap. *Singletone, $* *$ Doubletones.

Supplementary material 3 - Variation of temperature (a), relative humidity (b), canopy cover (c) and precipitation (d) between the sampling seasons on both fragments. Bars indicate CI.

\section{Acknowledgements}

The first author is especially thankful to the "Primera convocatoria interna para apoyo al desarrollo de trabajos de grado en investigación formativa-nivel pregrado y posgrado 2018", of the Universidad de Atlántico (Colombia), resolution number 002047 of December 10, 2018. We are thankful to Antonio Santos-Silva, Sônia Casari, and Francisco Eriberto de Lima Nascimento (MZSP) for their support and assistance in the identification of the specimens; to Francisco E. L. Nascimento for the design of the map; to Eugenio Nearns (United States Department of Agriculture, Animal and Plant Health Inspection Service, National Identification Services; National Museum of Natural History, Smithsonian Institution) and Larry Bezark for reviewing the English text; to the anonymous reviewers for their helpful suggestions during revision which helped to improve the manuscript; to Felipe Noguera (UNAM) and Sandy García (Universidad del Atlántico) for their suggestions on the preliminary version of this work. We are also grateful to the NEOPTERA team, especially to Jeniffer Meriño and José Sarmiento, for their help during sampling; to Santiago and Rafael Coronado, Oscar García and Adalberto García for their collaboration on sampling. The first and third authors are grateful to the "Fundação de Amparo à Pesquisa do Estado de São Paulo" (FAPESP) for their fellowship (process number 2019/13603-1 and 2017/17898-0, respectively). This research was made under the sampling permission granted by the Autoridad Nacional de Licencias Ambientales (ANLA) in Colombia, resolution number 00949.

\section{Author Contributions}

Kimberly García: contributed with the material preparation, data collection, identification, statistical analysis and interpretation, the manuscript preparation, and read and approved the final manuscript.
Neis Martinez: contributed with the study conception and design, statistical analysis and interpretation, the manuscript preparation, and read and approved the final manuscript.

Juan Pablo Botero: contributed with the identification, the manuscript preparation, and read and approved the final manuscript.

\section{Conflicts of Interest}

The authors declare that they have no conflict of interest related to the publication of this manuscript.

\section{References}

ACEVEDO, Á. 2016. Materiales educativos sobre uso y conservación del bosque seco tropical en el Caribe colombiano: una guía para facilitadores. Tropenbos Internacional Colombia \& Fondo Patrimonio Natural, Bogotá.

AMAT, G. 2007. Fundamentos y métodos para el estudio de los insectos. Pro offset editorial S.A., Bogotá.

BASELGA, A. \& ORME, D. 2012. Betapart: an R package for the study of beta diversity. Methods Ecol. Evol. 3:808-812.

BASELGA, A. 2008. Determinants of species richness, endemism and turnover in European longhorn beetles. Ecography 31:263-271.

BASELGA, A. 2010. Partitioning the turnover and nestedness components of betadiversity. Global Ecol. Biogeogr. 19:134-143.

BOTERO, J.P. 2018. La familia Cerambycidae (Coleoptera: Chrysomeloidea) en Colombia. In Escarabajos del neotrópico (Insecta: Coleoptera) (C. Deloya \& H. Gasca, eds). S \& G editores, México, p.153-170.

BOUGET, C. 2005. Short-term effect of windstorm disturbance on saproxylic beetles in broadleaved temperate forests - Part I: Do environmental changes induce a gap effect?. Forest Ecol. Manag. 216:1-14.

BRAY, J. \& CURTIS, J. 1957. An ordination of the upland forest communities of southern Wisconsin. Ecol. Monogr. 27:326-349.

CALDERÓN-PATRÓN, J., C. MORENO \& I. ZURIA. 2012. La diversidad beta: medio siglo de avances. Revista Mexicana de Biodiversidad 83: 879-891.

CANCINO, R., CHAME, E. \& GÓMEZ, B. 2014. Escarabajos necrófilos (Coleoptera: Scarabaeinae) en tres hábitats del Volcán Tacaná, Chiapas, México. Dugesiana 21: 135-142.

CAVA, M., COSCARON, M. \& CORRONCA, J. 2015. Inventario y estimación de la riqueza específica de artrópodos en bosques del noreste de Argentina. Rev. Colomb. Entomol. 41:139-146.

CHAO, A., GOTELLI, N.J., HSIEH, T.C., SANDER, E.L., MA, K.H. \& ELLISON, A.M. 2014. Rarefaction and extrapolation with Hill numbers: a framework for sampling and estimation in species diversity studies. Ecol. Monogr. 84:45-67.

CLARKE, K. \& GORLEY, R. 2006. PRIMER v6: User manual/Tutorial. PRIMER-E, Plymouth.

FARRELL, B.D. \& MITTER, C. 1998. The timing of insect/plant diversification: might Tetraopes (Coleoptera: Cerambycidae) and Asclepias (Asclepiadaceae) have co-evolved? Biol. J. Linn. Soc. 63:553-577.

FUENTES-RODRÍGUEZ, D., FRANCESCHINI, C., SOLANGE, F. \& SOSA, A. 2017. Herviboría de los insectos específicos Cornops aquaticum (Orthoptera: Acrididae) y Neochetina (Coleoptera: Erirhinidae): comparación entre especies hospederas y periodos de crecimiento de las poblaciones de plantas. Rev. Mex. Biodivers. 88:674-682.

GARCÍA, K. 2019. New species, new geographical records of Neoibidionini and description of the females of Compsibidion paradoxum Martins, 1971 and Glomibidion trinidadense (Gilmour, 1963) (Coleoptera: Cerambycidae). Ann. Soc. Entomol. Fr. 1-11.

GARCÍA, K. \& NASCIMENTO, F.E.L. 2020. Elaphidiini (Coleoptera, Cerambycidae) from the Caribbean region of Colombia: New species, taxonomic notes and new geographical records. Pap. Avulsos Zool. 60:1-8. 
GARCÍA, K., BOTERO, J.P. \& MARTÍNEZ, N. 2019. New species and new geographical records in South American Piezocerini (Coleoptera: Cerambycidae) with revised keys to species of Alienosternus and Hemilissa. Can. Entomol. 1-18.

GARCÍA-L, K.P., NASCIMENTO, F.E.L. \& MARTÍNEZ-HERNANDEZ, N.J. 2019. A new species, new distribution records, and taxonomic notes in Lamiinae (Coleoptera: Cerambycidae) from Colombia. Zootaxa. 4559 (2): 363-372.

GARCÍA-ATENCIA, S. \& MARTÍNEZ-HERNÁNDEZ, N. 2015. Escarabajos fitófagos (Coleoptera: Scarabaeidae) del Departamento del Atlántico, Colombia. Acta Zool. Mex. 31:89-96.

GATTI, F., ARAUJO, T., DIAS, L. \& ALVES, M. 2018. Longhorn beetle (Coleoptera: Cerambycidae) assemblage and the structural heterogeneity of habitat at the brazilian atlantic forest. Environ. Entomol. 47:1413-1419.

GUTIÉRREZ, N., MÁRQUEZ, J. \& NOGUERA, F.A. 2014. Cerambycidae (Insecta: Coleoptera) de una localidad con bosque mesófilo de montaña en Hidalgo, México. Dugesiana 21:143-150.

HAACK, R., KEENA, M. \& EYRE, D. 2017. Life history and population dynamics of Cerambycids. In Cerambycidae of the world: biology and pest management (Q. Wang, ed.). CRC Press, p.71-104.

HAMMER, O., HARPER, D. \& RYAN, O. 2001. PAST: Palentontological statistics software package for education and data analysis. Palaeontol. Electron. 4:1-9.

HARRISON, S., ROSS, S.J. \& LAWTON, J.H. 1992. Beta diversity on geographic gradients in Britain. J. Anim. Ecol. 61:151-158.

HERAZO-VITOLA, F., MERCADO, J. \& MENDOZA, H. 2017. Estructura y composición florística del bosque seco tropical en los montes de maría (Sucre-Colombia). Cienc. Desarro. 8:71-82.

HJÄLtÉn, J., STENBACKA, F., PETTERSSON, R.B., GIBB, H., JOHANSSON, T., DANELL, K., BALL, J.P. \& HILSZCZAŃSKI, J. 2012. Micro and macro-habitat associations in saproxylic beetles: implications for biodiversity management. PLoS ONE 7: e41100.

HOLDRIDGE, L. 1978. Ecología basada en zonas de vida. Instituto interamericano ciencias agrícolas, San Jose.

JOST, L. 2006. Entropy and diversity. Oikos 113:363-375.

KATTAN, G.H. \& ALVAREZ-LÓPEZ, H. 1996. Preservation and management of biodiversity in fragmented landscapes in the Colombian Andes. In Forest patches in tropical landscapes (J. Schelhas \& R. Greenberg, eds). Island Press, Washington, p.3-18

KATTAN, G., SÁNCHEZ, C., VÉLEZ, C., RAMÍREZ, L. \& CELIS, M. 2019. Beta diversity and knowledge gaps of Colombia's dry forests: implications for their conservation. Caldasia 41:1-11.

MAES, J., BERGHE, E., DAUBER, D., AUDUREAU, A., NEARNS, E., SKILLMAN, F., HEFFERN, D. \& MONNÉ, M. 2010. Catálogo de los Cerambycidae de Nicaragua. Rev. Nicar. Entomol. 70: 76.

MAETO, K., SATO, S. \& MIYATA, H. 2002. Species diversity of longicorn beetles in humid warm temperate forests: the impact of forest management practices on old. Growth forest species in southwestern Japan. Biodivers. Conserv. 11:1919-1937.

MARTÍNEZ, C. 2000. Escarabajos Longicornios (Coleoptera: Cerambycidae) de Colombia. Biota Colombiana 1:76-105.

MARTÍNEZ, N.J., CAÑAS, L.M., RANGEL, J.L., BARRAZA, J., MONTES, J. \& BLANCO, O. 2010. Coleópteros coprófagos (Scarabaeidae: Scarabaeinae) en un fragmento de bosque seco tropical en el departamento del Atlántico, Colombia. Bol. Mus. Entomol. Univ. Val. 11:21-30.

MARTINS, U. 2007. Cerambycidae sul-americanos (Coleoptera). Taxonomia. Volume 9. Subfamilia Cerambycinae: Ibidionini Thomson, 1860, sub tribo Tropidina subtrib. n., Subtribo Ibidionina Thomson, 1860. Sociedade Brasileira de Entomologia, Curitiba.

MENDOZA, H. 1999. Estructura y riqueza florísitica del bosque seco tropical en la región caribe y el valle del río magdalena, Colombia. Caldasia 21:70-94.

MENG, L., MARTIN, K., WEIGEL, A. \& YANG, X. 2013. Tree diversity mediates the distribution of longhorn beetles (Coleoptera: Cerambycidae) in a changing tropical landscape (Southern Yunnan, SW China). PLoS ONE 8: e75481.
MILES, L., NEWTON, A.C., DEFRIES, R.S., RAVILIOUS, C., MAY, I., BLYTH, S., KAPOS, V. \& GORDON, J.E. 2006. A global overview of the conservation status of tropical dry forests. J. Biogeogr. 33:491-505.

MONTAÑO, S., CAMARGO, S., GRETHER, R. 2016. Anatomía de la madera de tres especies de Mimosa (Leguminosae-Mimosoideae) distribuidas en México. Madera Bosques 22:191-202.

MORRONE, J. \& ESCALANTE, T. 2016. Introducción a la biogeografía. Universidad nacional autónoma de México, México.

NOGUERA, F. 2014. Biodiversidad de Cerambycidae (Coleoptera) en México. Rev. Mex. Biodivers. 85:290-297.

NOGUERA, F.A, ORTEGA-HUERTA, M.A., ZARAGOZA-CABALLERO, S., GONZÁLEZ-SORIANO, E. \& RAMÍREZ-GARCÍA, E. 2017. Species Richness and Abundance of Cerambycidae (Coleoptera) in Huatulco, Oaxaca, Mexico; Relationships with Phenological Changes in the Tropical Dry Forest. Neotrop. Entomol. 47:457-469.

NOGUERA, F.A., ZARAGOZA-CABALLERO, S., CHEMSAK, J.A., RODRÍGUEZ-PALAFOX, A., RAMÍREZ, E., GONZÁLEZ-SORIANO, E. \& AYALA, R. 2002. Diversity of the Family Cerambycidae (Coleoptera) of the Tropical Dry Forest of Mexico, I. Sierra de Huautla, Morelos. Ann. Entomol. Soc. Am. 95:617-627.

NOGUERA, F., CHEMSAK, J., ZARAGOZA-CABALLERO, S., RODRIGUESPALAFOX, A., RAMÍREZ, E., GONZÁLES-SORIANO, E. \& AYALA, R. 2007. A faunal study of Cerambycidae (Coleoptera) from one region with tropical dry forest in Mexico: San Buenaventura, Jalisco. The pan-pacific entomologist 83:296-314.

NOGUERA, F., ZARAGOZA, S., RODRÍGUEZ, A., GONZALES, E., RAMÍREZ, E., AYALA, R. \& Ortega, M. 2012. Cerambícidos (Coleoptera: Cerambycidae) del bosque tropical caducifolio en Santiago Dominguillo, Oaxaca, México. Rev. Mex. Biodivers. 83:611-622.

NOGUERA, F., ORTEGA-HUERTA, M., ZARAGOZA-CABALLERO, S., GONZALEZ-SORIANO, E. \& RAMÍREZ, E. 2009. A faunal study of Cerambycidae (Coleoptera) from one region with tropical dry forest in Mexico: Sierra de San Javier, Sonora. The pan-pacific entomologist 85:70-90.

NORIEGA, J., BOTERO, J., VIOLA, M. \& FAGUA, G. 2007. Dinámica estacional de la estructura trófica de un ensamblaje de Coleoptera en la Amazonia Colombiana. Rev. Colomb. Entomol. 33:157-164.

NORIEGA, J., PALACIO, J., MONROY, J. \& VALENCIA, E. 2012. Estructura de un ensamblaje de escarabajos coprófagos (Coleoptera: Scarabaeinae) en tres sitios con diferente uso del suelo en Antioquia, Colombia. Actual. biol. 34:43-54.

OKSANEN, J., BLANCHET, F.G., FRIENDLY, M., KINDT, R., LEGENDRE, P., MCGLINN, D., MINCHIN, P.R., O'HARA, R.B., SIMPSON, G.L., SOLYMOS, P., STEVENS, M.H.H., SZOECS, E. \& WAGNER, H. 2017. Vegan: Community Ecology Package. R package version 2.4-0. https:// CRAN.R-project.org/package=vegan.

OTERO, E., MOSQUERA, L., SILVA, G. \& GUZMAN, J. 2006. Bosque seco tropical Colombia. Banco de Occidente, Bogotá.

PARO, C., ARAB, A. \& VASCONCELLOS-NETO, J. 2014. Specialization of Atlantic rain forest twig-girdler beetles (Cerambycidae: Lamiinae: Onciderini): variation in host-plant use by microhabitat specialists. Arthropod-Plant Inte. 8:557-569.

PÉREZ, C. \& ZARAGOZA, S. 2015. Diversidad alfa y beta de Cantharidae (Coleoptera) en el bosque tropical caducifolio de la vertiente del pacífico mexicano. Rev. Mex. Biodivers. 86:771-781.

PIZANO, C. \& GARCÍA, H. 2014. El bosque seco tropical en Colombia. Instituto de investigación de recursos biológicos Alexander von Humboldt (iAvH), Bogotá.

RAMÍREZ, R. 2012. Coleopterofauna (Lamelicornia y Longicornia) del bosque premontano El Rodeo, cantón de Mora, Costa Rica. Brenesia 77:297-328.

RANGEL, J. \& MARTíNEZ, N. 2017. Comparación de los ensamblajes de escarabajos copronecrófagos (Scarabaeidae: Scarabaeinae) entre fragmentos de bosque seco tropical y la matriz adyacente en el departamento del Atlántico-Colombia. Rev. Mex. Biodivers. 88:389-401. 
RANGEL-CH, J. \& CARVAJAL-COGOLLO, J. 2012. Suelos de la región Caribe de Colombia. In Diversidad Biótica, tomo XII (J. RANGEL-CH, ed.). Universidad nacional de Colombia, Bogotá, p.879-921.

RODRÍGUEZ, G., BANDA, K., REYES, S. \& ESTUPIÑAN, A. 2012. Lista comentada de las plantas vasculares de bosques secos prioritarios para la conservación en los departamentos Atlántico y Bolívar (Caribe colombiano). Biota Colombiana 12:7-39.

RODRÍGUEZ, P., SOBERON, J. \& ARITA, H.T. 2003. El componente beta de la diversidad de mamíferos de México. Acta Zoológica Mexicana 89, 241-250.

ROMERO, J., CHEMSAK, J. \& RODRÍGUEZ, C. 2007. Some notes on natural history and distribution of Leptostylus gibbulosus Bates, 1874 (Coleoptera: Cerambycidae). Acta Zoológica Mexicana 23:171-173.

SATARAL, M., ATMOWIDI, T. \& NOERDJITO, W. 2015. Diversity and abundance of longhorn beetles (Coleoptera: Cerambycidae) in Gunung Walat Educational Forest, West Java, Indonesia. Journal of Insect Biodiversity $3: 1-12$.

SUAREZ, S. \& VARGAS, O. 2019. Composición florística y relaciones ecológicas de las especies de borde, parches y árboles aislados de un bosque seco tropical en Colombia. Implicaciones para su restauración ecológica. Caldasia 41:28-41.

SUGIARTO, BOER, C., MARDJI, D. 2016. Species diversity of cerambycid beetles at reclamation area of coal mining in Berau District, east Kalimantan, Indonesia. Biodiversitas 17, 200-207.

ŠVÁCHA, P. \& LAWRENCE, J.F. 2014. Cerambycidae. Handbook of Zoology, Coleoptera Volume 3: Morphology and systematics (XX, Chrysomeloidea, Curculionoidea). In Handbuch der Zoologie/Handbook of Zoology. Volume IV Arthropoda: InsectaTeilband/Part 38. Coleoptera, Beetles. (R.G. Beutel, R.A.B. Leschen \& J.F. Lawrence JF, eds). Berlin, p.77-177.

TAVAKILIAN, G. \& CHEVILLOTTE, H. 2020. Titan: base de données internationales sur les Cerambycidae ou Longicornes. Version 3.0. http:// titan.gbif.fr/ Accessed 5 Mar. 2020.
TER-BRAAK, C. 1986. Canonical correspondence analysis: A new eigenvector technique for multivariate direct gradient analysis. Ecology 67:1167-1179.

TOLEDO, V., CORONA, A. \& MARTINEZ, J. 2014. Cerambycidae (Coleoptera) como parte del complejo saproxilófago en selva baja caducifolia. Entomología mexicana 1:565-569.

TRAPERO, A. \& REYES, B. 2017. Patrones de emergencia de Odonata (Insecta) en un hábitat lótico de Cuba oriental. Rev. Biol. Trop. 65:807-818.

VALDEZ, J., GONZALES, M. \& DE LOS SANTOS, H. 2006. Estimación de cobertura arbórea mediante imágenes satelitales multiespectrales de alta resolución. Agrociencia 40:383-394.

VARGAS, M., BOOM, C., SEÑA, L., ECHEVERRY, A. \& MARTÍNEZ, N. 2015. Composición vegetal, preferencias alimenticias y abundancia de Biblidinae (Lepidoptera: Nymphalidae) en un fragmento de bosque seco tropical en el departamento del atlántico, Colombia. Acta Biol. Colomb. 20:79-92.

VENABLES, W.N. \& RIPLEY, B.D. 2002. Modern Applied Statistics with S, Fourth edition. Springer, New York.

VILLAREAL, E., MARTÍNEZ, N. \& ROMERO-ORTIZ, C. 2019. Diversity of Pseudoscorpiones (Arthoropoda: Arachnida) in two fragments of dry tropical forest in the colombian Caribbean region. Caldasia 41:139-151.

VITALI, F., WOLF, K. \& HAZAIRE, J. 2006. Biological and faunistic notes on the Jamaican population of Steirastoma histrionicum White, 1855 (Coleoptera, Cerambycidae). Lambillionea 4:661-667.

WHITTAKER, R. 1965. Dominance and diversity in land plant communities: Numerical relations of species express the importance of competition in community function and evolution. Science 147:250-60.

Received: $21 / 09 / 2020$

Revised: 01/01/2021

Accepted: 13/06/2021

Published online: 13/09/2021 